\title{
Respiratory System Findings Test Code
}

National Cancer Institute

\section{Source}

National Cancer Institute. Respiratory System Findings Test Code. NCI Thesaurus. Code C124027.

A character or string that represents the short code name of the respiratory system findings assessment. 